\title{
The Victorian Complex in Byatt 's Novel Creation
}

\author{
Zhou Hong \\ Changsha Medical University Huanan Changsha 410000
}

\begin{abstract}
Byatt is a well-known novelist and literary critic in the 20th century British literary world. He was named one of the 50 greatest writers of the English literary world since 1945. Her most successful work is "possession" (also translated as "hidden book") won the highest award of British literature - Booker novel award. This novel has brought great reputation to Byatt, laid her important position in the English literary world and the world literary world, caused a worldwide research boom, but also won the media, critics and readers unanimously approved . Byatt's novels include letters, poems, diaries, fairy tales and other narrative material, describing the story of the time span from ancient times to the Victorian era and then to contemporary society, such a huge system called the postmodern classic . "Possession" strongly expresses the postmodern features of intense novels, and this feature just confirms the Victorian complex created by Byatt's novels.

Keywords: Byatt, "possession", creation, Victoria, complex
\end{abstract}

\section{Introduction}

Text: Byat was born on August 24, 1936, in Sheffield. Her father was John Drabble and his mother was a scholar of Browning. So the girl's real name was Antonia Susan Drabble. Her sister Margaret Drabble (1939 -) is also a famous British novelist. Byatt was enrolled in Sheffield Middle School and Paget Montessori Secondary School. Later at the University of Cambridge, University of Oxford and University of Oxford. He taught at the University of London from 1962 to 1971 and from 1972 to 1983 at the University College London. Is a 
member of the Royal Society of British literature, specializing in the British writer Iris Murdoch (Iris Murdoch).

With the accumulation of literary creation for a long period of time, Byatt's novel style is characterized by rich changes, and narrative techniques can continue to introduce new ideas. Therefore, her writing in the English-speaking countries have gradually been people's attention and concern. Her fifth novel, "possession" in 1990, the British authoritative novel book prize, the same year, won the Irish international novel award. It can be said that her creative career has reached a new peak.

"Possession" will always be considered "concept" novel. This work is not only rich and vivid, express the original ecology of life, but also for the rumination of life, open the reader's mind, deepen the understanding of life for the deepening. The novels are the same as her other works. They are rich in content, while other novels use the structure of reasoning novels, which makes suspenseful stories more exciting.

If Byatt novels full of Victoria complex, then how is this reflected it? Before I can explore this question, I had to introduce the relevant links to the Victorian complex. Then the first to know the "Victorian era."

Queen Victoria (Alexandra Victoria, Alexandrina Victoria in 1837 inherited the throne (when she was 18 years old), the reign of 63 years (June 20, 1837 to January 22, 1901), is the most The so-called "empire" period, during her reign until her death, to the beginning of the first world war in 1914, the United Kingdom are called the Victorian era, after 1914, the United Kingdom began to decline.

Victorian era (Victorian era), before the George era, after the opening of the Edwardian era, the world recognized as the British Industrial Revolution and the British Empire peak. Its duration is defined as the period from 1837 to 1901, that is, the reign of Queen Victoria (Alexandrina Victoria). Some scholars believe that the reform Act 1832 (Reform Act 1832) should be regarded as the beginning of a new cultural period. Victorian era is considered the peak period of the British industrial revolution, but also the economic and cultural heyday of the British Empire.

Victorian scientific inventions wave surging, Victorian belief in scientific progress, for the industrial revolution is full of optimism and confidence. The emergence of steamship makes transport and trade reached an unprecedented prosperity, extensive rail traffic runs through the north and south.

Victorian era in the art world showing the stars brilliant eye-catching scene. At the time of the literary movement schools, including classicalism, romanticism, Impressionist art, neoclassicism, and post-impressionist.

Victorian English society to advocate humility and courtesy and moral cultivation is known, but also a social science, cultural economy and industry have great development of the prosperity of the sun never empire. At that time the United Kingdom in the literature and art to achieve unprecedented prosperity, this period also formed a gender equality and racial equality concept of progress, the community showing a thriving rising situation. 
The middle and upper classes of that era were very particular about the diet, they imported from the distant country a variety of exotic spices, spices, for the well-cooked food. Victoria has the history of the earliest cooking school, cooks cooking books prepared by the popular British, in this era of the earliest specific cooking methods such as spices and other details into the book. Some small kitchen utensils are also popular, such as the can opener, the Victorian era also formed a lot of meal etiquette.

During this period, the prevalence of afternoon tea in Britain, the rich nobility breakfast, lunch is simple, late supper. It is said that Queen Victoria's daughter-in-law, Anna, was so hungry every afternoon that she served her servants with small refreshments. Many people followed suit, and afternoon tea became a regular ritual. In fact, around this tea customs formed a colorful tea culture, elegant hotel began to set up tea room, the streets have opened to the public teahouse, tea party dance has become a social form, the lady of the Victorian era They were there to meet with her boyfriend.

This fascinating era, the British people are experiencing everything is so beautiful, and with the Japanese empire does not set the title of world hegemony on the summit of the world nation. And this day did not end with the death of Queen Victoria. Many historians believe that the so-called "Victorian era" is the real end, after the end of the First World War. The collapse of the Crystal Palace during the first world expo declared the end of the Victorian era.

Byatt 's Victorian complex of fictional writing was exactly what Byatt lived in the United Kingdom during the Second World War and the end of the Victorian era after the relevant. Byatt was born in the decade before the Second World War, when the world has been the rise of other major powers began to challenge the British hegemony, such as the United States, Germany and other countries. Byatt was one of those who witnessed the end of the Victorian era in this context.

Britain is the first industrial revolution, the country has accounted for more than half of the earth, known as the Empire never fall, the Navy is the world's long-term ranks first, military, technology, systems, culture is the example of the Western world. After the end of World War II, the British national strength decline, but at that time the United Kingdom is only weak than the United States and the Soviet Union, why the development to the present, France, Germany and Japan are more than.

After World War II is not only the British lonely, then light on the money to spend a lot of time, but in World War II they owe the United States a lot of shallow thinking rigid, the European economic situation is not good. World War II can be said to completely destroy the European economy. But Germany and France and other countries because the United States a large number of aid, and these countries already have a very good economic and political foundation, so in the post-war recovery and development of high innovation.

After the war the British colonies have been independent, such as South Africa, India, Pakistan, Canada, Australia, New Zealand also belong to the Commonwealth, and the United Kingdom basically nothing. In addition to BAE, Rolls Royce and several other well-known brands, the relative high-end manufacturing is the same amount of Germany, Japan, a comprehensive 
repression. With the Anglo-Saxon culture, to see has been nearly a hundred years ahead of the United States is still energetic, but also showed great splendor of the British Empire's lonely.

At that time, the United Kingdom from the incomparable glory to decline, on the one hand for the rise of other powers become powerless, on the other hand for the slow and difficult development of their own country and unwillingness. In such a situation, the majority of the British people will inevitably produce a glorious past for the Japanese Empire's expectations and longing. Victorian era is considered the peak period of the British industrial revolution, but also the economic and cultural heyday of the British Empire. Has been the British people as the most proud of history, and this history can not always be there. In the aftermath of the decline or other powers to the more than the scene will become increasingly prominent over time. From the beginning of the second industrial revolution, the rise of the United States, Germany, Japan and other countries have begun to challenge the authority of British hegemony. The best embodied is the two world wars, and after the Second World War the British eventually to the destruction of the overlord of the road. In such a scenario, the British can not help but imagine the glory of the past and lamented the reality of the helpless. At this time Byatt is such a social influence to grow up, inevitably will be with a strong Victorian complex.

For a woman, from small to large continuous reduction and disillusionment is for romantic imagination and dream. With age, they were injured by time and space, gradually leaving a light of their own. May have the opportunity to try a Victorian dream, I am afraid no woman will refuse? So the Victoria complex for women should be very common. Especially for female writers for Victoria should have a persistent and special strong feelings.

There are many great writers, poets and their works in the Victorian era, such as the British writer Charlotte Bronte (Jane Eyre) and the famous realist novelist Charles Dickens ")Wait. Social climate Victorian to advocate moral cultivation and humility courtesy is known, but also a science, culture and industry have been greatly developed the prosperity of the peace and prosperity. The development of the printing industry to promote the unprecedented prosperity of literature and art, this period also formed a gender equality and racial equality of progressive ideas, the United States of the abolitionist movement is the embodiment of this progressive thinking. The middle and upper classes of that era were very particular about the diet, they imported from the distant country a variety of exotic spices, spices, for the well-cooked food. Victoria has the history of the earliest cooking school, cooks cooking books prepared by the popular British, in this era of the earliest specific cooking methods such as spices and other details into the book. Some small kitchen utensils are also popular, such as the can opener, the Victorian era also formed a lot of meal etiquette. During this period, the prevalence of afternoon tea in Britain, the rich nobility breakfast, lunch is simple, late supper. It is said that Queen Victoria's daughter-in-law, Anna, was so hungry every afternoon that she served her servants with small refreshments. Many people followed suit, and afternoon tea became a regular ritual. In fact, around this tea customs formed a colorful tea culture, elegant hotel 
began to set up tea room, the streets have opened to the public teahouse, tea party dance has become a social form, the lady of the Victorian era They were there to meet with her boyfriend. This is not a fascinating era? Therefore, for a woman, especially for the women of literature and art to pursue such an era has become reasonable.

The Victorian era did not end with the death of Queen Victoria. But after the end of the First World War. The collapse of the Crystal Palace during the first World Exposition declared the end of the Victorian era. After the Second World War, the situation in the United Kingdom is worse and can not and has been compared, so in the subsequent British society for the Victoria complex memorial nature from that gone for a longer period of time away and miss the more Is profound.

As the "Victorian and postmodern historical imagination: Byatt" New Victorian novel "research" concerned, try to analyze the filter process itself embodies the cultural criticism, meaning that the Western intellectuals classical human feelings and The spiritual exploration and the crisis under the impact of postmodern thought, which are highlighted by the Victorian complex created by Byatt's novels. We explore Byatt's novels and her creative features when it should be more often combined with her time background and the general public's ideological pursuit, so hidden in the majority of the British people is also in the hearts of Byatt in Victoria Complex becomes natural to be justified or forgiven. Byatt as such a time in a creator in her heart will inevitably be pregnant with an irrevocable Victorian complex.

\section{Acknowledgements}

Fund Project: 2015 Hunan Social Science Fund Foreign Language Research Joint Projec. An Anlysis of the Cultural Reconstruction and Reality Contrast of the Neo-Victorian Novel Possession Item Number: 15WLH03

\section{References}

1, Cheng Qian; Returning to the History of History - Analysis of Byatt's Possession of Historical Narrative Strategy [J]; Foreign Literature; 2003-01

2, Cheng Qian; The Way of Returning to History - On the Historical Narrative Strategy of Byatt's "Possession" [J]; Foreign Literature; 2003-01

3, Cheng Qian ;; History of the cycle - Byatt's novel "possession" of the plot structure prototype $[\mathrm{J}]$; Foreign Literature;

4, Cheng Qian; Byatt and her magic book "possession" [N]; Chinese reading newspaper; 2003

5, Liu Aiqin; A.S. Byatt's novel of gender issues [D]; Shandong University; 2009

6, Hanzhaojing; Byatt's "possession" of ecological feminist interpretation [D]; Liaoning Normal University;

7, He Fang, "possession" of the narrative strategy [D]; Hebei Normal University; 